Taylor \& Francis Group, LLC

ISSN: 0895-8378 print /1091-7691 online

DOI: $10.1080 / 08958370500515913$

\title{
Relation Between Sources of Particulate Air Pollution and Biological Effect Parameters in Samples from Four European Cities: An Exploratory Study
}

\section{Peter A. Steerenberg1, Ludo van Amelsvoort2, Martinus Lovik3, Ragna B. Hetland3, Torunn Alberg3, Tadeusz Halatek4, Henk J. T. Bloemen 1, Konrad Rydzynski4, Gerard Swaen2, Per Schwarze3, Erik Dybing3 and Flemming R. Cassee*1}

1National Institute for Public Health and the Environment, Bilthoven, The Netherlands.

2Department of Epidemiology, Maastricht University, Maastricht, The Netherlands.

3Division of Environmental Medicine, Norwegian Institute of Public Health, Oslo, Norway.

4Nofer Institute of Occupational Medicine, Lodz, Poland.

*Correspondence: Flemming R. Cassee, Centre for Environmental Health

Research, National Institute for Public Health and the Environment, PO Box 1, Bilthoven, 3720, BA, The Netherlands; E-mail: f.cassee@rivm.nl

Given that there are widely different prevalence rates of respiratory allergies and asthma between the countries of Europe and that exposure to ambient particulate matter (PM) is substantial in urban environments throughout Europe, an EU project entitled "Respiratory Allergy and Inflammation Due to Ambient Particles" (RAIAP) was set up. The project focused on the role of physical and chemical composition of PM on release of cytokines of cells in vitro, on respiratory inflammation in vivo, and on adjuvant potency in allergy animal models. Coarse $(2.5-10 \mu \mathrm{m})$ and fine $(0.15-2.5 \mu \mathrm{m})$ particles were collected during the spring, summer and winter in Rome (I), Oslo (N), Lodz (PL), and Amsterdam (NL). Markers within the same model were often well correlated. Markers of inflammation in the in vitro and in vivo models also showed a high degree of correlation. In contrast, correlation between parameters in the different allergy models and between allergy and inflammation markers was generally poor. This suggests that various bioassays are needed to assess the potential hazard of PM. The present study also showed that by clustering chemical constituents of PM based on the overall response pattern in the bioassays, five distinct groups could be identified. The clusters of traffic, industrial combustion and/or incinerators (TICI), and combustion of black and brown coal/wood smoke (BBCW) were associated primarily with adjuvant activity for respiratory allergy, whereas clusters of crustal of material (CM) and sea spray (SS) are predominantly associated with measures for inflammation and acute toxicity. The cluster of secondary inorganic aerosol and long-range transport aerosol (SIALT) was exclusive associated with systemic allergy. The present study has shown that biological effect of PM can be linked to one or more PM emission sources and that this linkage requires a wide range of bioassays. 
Health effects of air pollutants have been related to mass concentration of airborne particulate matter (Dick et al., 2003; Ghio et al., 2003; Motallebi et al., 2003; Voelkel et al., 2003). For some particles it has been shown that size or surface area is a more important factor than mass (Donaldson et al., 2003), and some studies have suggested that particle number may also be important (Nygaard et al., 2004). But particulate matter is a heterogeneous and complex mixture varying in its composition, dependent on site, season, weather conditions, and sources of emission (Lee, 2001; Long et al., 2001; Watson \& Chaw, 2001; Zhu et al., 2001). Thus, the surface area may be a measure surrogate for particle surface activity or the bound soluble components. Urban particulate matter (PM) represents particles either emitted directly by pollution sources, generated by reactions that occur in the atmosphere, or produced by erosion/destruction of surfaces and later resuspension. Elemental and organic carbon, sulfate, nitrate, chloride, ammonium, metals, organic compounds, mineral, and biological materials are major components of particulate air pollution (Marcazzan et al., 2003b). Most of these have been shown to elicit biological responses in experimental systems consistent with detrimental effects on human health (Gavett et al., 2003; Lambert et al., 1999, 2000). However, estimating the contributions of single components of PM is difficult and might miss the interaction among components of complex mixtures. It is therefore recommended to study the effects of the mixture itself (Feron et al., 1995) and subsequently identify the contributing, effect-inducing sources of emissions (Lee, 2001; Marcazzan et al., 2003a; Watson \& Chow, 2001).

Studies have attempted to tie daily mortality to certain categories of compounds thus trying to establish a connection between a source and a health outcome (Pope et al., 1999; Dye et al., 2001). Although statistically significant associations between components and daily mortality were detected, the data do not unequivocally identify a specific category of compounds causally related to the health outcome. (Quant et al., 2003)

The biological outcomes often measured in toxicological models comprise parameters linked to health effects, such as inflammation including influxes of polymorph nuclear leukocytes. In the adjuvant effect models for allergy, valid markers are the production of allergen-specific immunoglobulin $\mathrm{E}$ (IgE) and the occurrence of eosinophilic inflammation in the lung. In the popliteal lymph node assay also, cell proliferation has been included as an indicator. In neutrophilic inflammation, indicating a Th-1-mediated response, the markers may include cytokine release (interleukin [IL] 8; Il-6; tumor necrosis factor [TNF]-a), protein content changes of the bronchoalveolar lavage (BAL) fluid, and neutrophilic influx. In addition, markers of lung damage such as lactate dehydrogenase or Clara-cell protein levels are of interest.

In the RAIAP project we assessed the role of possible sources in causing local inflammation in the respiratory tract and induction and elicitation of respiratory allergies. More specifically, representative particle samples from a western, an eastern, a northern, and a southern European city and a seaside site were physically, chemically, and immunologically characterized and subsequently screened for allergenic and inflammatory potential, see for details (Cassee \& Boere, 2001; Dybing et al., 2004; Hetland et al., 2004; Steerenberg et al., 2004a, 2004b, 2005). In the present study we have put together a selection of representative data from the various in vitro and in vivo bioassays used in the RAIAP project. We hypothesized that outcomes from studies were predictive for the results obtained in the in vivo studies. Second, the biological effect will vary based on the contribution of specific sources, with PM from anthropogenic origin being the most potent source. To address these hypotheses, correlation coefficients for all the outcomes of the bioassay have been calculated. In addition, 
all chemical characteristics of the PM samples were related to the bioassay outcomes. Subsequently, chemicals that resulted in a similar pattern of response were clustered. The clusters were then associated with the major contributing source.

\section{MATERIAL AND METHODS}

\section{Particle Sampling Campaign}

\section{Particle Collection}

A high-volume cascade impactor with a multistage round slit nozzle impactor was used to collect PM fractions into a methanol-cleaned polyurethane foam (PUF) by impaction (Demokritou et al., 2001, 2002). The selected stages for the RAIAP project used cut points at $8.5,2.35$, and $0.12 \mu \mathrm{m}$ mass median aerodynamic diameter. The fractions $8.5-2.35 \mu \mathrm{m}$ and $2.35-0.12 \mu \mathrm{m}$ are referred to as coarse and fine, respectively.

\section{Sampling Locations and Seasons}

The selection procedure of the five locations in Europe and the sampling periods have been extensively described earlier (Cassee \& Boere, 2001) The sampling campaigns lasted for 4 wk during winter, spring, and summer seasons, and the sites in Rome (Italy), Oslo (Norway), Lodz (Poland), and Amsterdam (the Netherlands) were located in the centers of cities with a large population, dominance of traffic, and nearby roads ( $>10 \mathrm{~m}$ and $<100 \mathrm{~m}$ ). With its prevailing southwesterly sea wind, very low levels of traffic emissions, and natural allergens such as pollen, De Zilk (the Netherlands) was selected as a rural background site.

\section{Particle Extraction From Substrate}

To perform chemical analysis and experiments, the PM was extracted from the PUF by methanol extraction based on a method described by Salonen and coworkers (Salonen et al., 2000). Samples were stored at $-20^{\circ} \mathrm{C}$ to prevent changes in the composition of PM due to evaporation or chemical reactions. To test the particle samples in the biological effect studies, samples were thawed, weighted, and dissolved in saline by vigorous shaking until a suspension was formed.

\section{Chemical Analysis}

\section{Elemental Composition}

The supplied methanol sample containing $0.1 \mathrm{mg}$ particulate matter was evaporated to dryness. Initially an existing multielement method with highresolution inductively coupled plasma mass spectrometer (HR-ICPMS) was used as a screening method, which was subsequently optimized and applied. This method included the following elements: $\mathrm{Li}, \mathrm{Be}, \mathrm{B}, \mathrm{Na}, \mathrm{Mg}, \mathrm{Al}, \mathrm{K}, \mathrm{Ca}, \mathrm{Ti}, \mathrm{V}, \mathrm{Cr}$, $\mathrm{Mn}, \mathrm{Fe}, \mathrm{Co}, \mathrm{Ni}, \mathrm{Cu}, \mathrm{Zn}, \mathrm{As}, \mathrm{Se}, \mathrm{Sr}, \mathrm{Mo}, \mathrm{Cd}, \mathrm{Sn}, \mathrm{Sb}, \mathrm{Ba}, \mathrm{Ce}, \mathrm{Nd}, \mathrm{Sm}, \mathrm{Au}, \mathrm{Hg}, \mathrm{Tl}$, $\mathrm{Pb}, \mathrm{Bi}$, and $\mathrm{U}$. $\mathrm{Hg}$ was not analyzed due to losses during digestion caused by its volatility. Si was determined in all samples, although the background Si might be large due to the use of glass containers. The calibration of Si was carried out as a one-point calibration. Rh was used as an overall internal standard. The samples were quantified with external 2-point calibration. For quality control of the whole procedure and for controlling the completeness of digestion, a standard reference material (10 mg NIST 2710 "Montana soil," National Institute of Standards and Technology, Gaithersburg, MD) was treated in the same way. Each digestion run included a procedural blank, which was used for the calculation of detection limits. The analyses were performed under the quality control/quality assurance (QC/QA) system of the laboratory. 


\section{Secondary Aerosol}

Samples, each containing $1 \mathrm{mg}$ particulate matter, were evaporated to dryness, dissolved in water by sonication, filtered to remove remaining particles, and analyzed using ion chromatography $(\mathrm{Cl}-, \mathrm{NO}-3$, and $\mathrm{SO} 2+4)$ or photometry $(\mathrm{NH}+4)$. The anions were analysed using a Dionex guard column (AG-4A), separation column (Dionex AS-4A), and pulsed electrochemical detector (DionexPED). Detection limits were $0.003,0.002$, and $0.001 \mathrm{mmol} / \mathrm{L}$ for $\mathrm{Cl}-, \mathrm{NO}-3$, and $\mathrm{SO} 2+4$, respectively

Polycyclic Aromatic Hydrocarbons (PAH) and C1-C32 Organic Compounds The sample containing approximately $6 \mathrm{mg}$ particulate matter was evaporated to dryness. An aliquot $(50 \mu \mathrm{l})$ of internal standards ( 6 deuterated PAHs and d2-C29aaa(20R)-ethylcholestane) and $50 \mathrm{ml}$ dichloromethane/isohexane (1:1) was added and the compounds were released by ultrasonic extraction. After filtration the extract was concentrated by evaporation nearly to dryness and mixed with $0.5 \mathrm{ml}$ standard solution of 2,4-dichlorobenzyl tetradecyl ether, which was used to correct for the variation of the injected volume. One microliter was injected (splitless mode) at $290^{\circ} \mathrm{C}$ on a $30-\mathrm{m}, 0.25-\mathrm{mm}$ WCOT DB-5MS column (film 0.25 $\mu \mathrm{m}$ ) using a column temperature programmed from $90-160-290^{\circ} \mathrm{C}$ in a Fisons 8000 series gas chromatograph equipped with an Interscience MD800 mass spectrometer with EI in SIR mode. Detection limits are approximately 0.1 $\mathrm{ng} /$ extract. From the $\mathrm{C} 1-\mathrm{C} 32$ organic compounds, hopanes and steranes were used as markers for traffic-derived combustion PM (diesel and gasoline exhaust)

\section{Endotoxins}

Endotoxin concentrations were determined using a Limulus amebocyte lysate (LAL) test (Limusate, Sigma Aldrich Chemie BV, Zwijndrecht, the Netherlands) as described by the manufacturer, with a detection level $<0.125 \mathrm{ng}$ endotoxin/ml. The LAL test may be substituted for the U.S. Pharmacopeia (USP) Endotoxin Pyrogen Test (EPT) and is recommended for the quantification of endotoxin in raw materials. The USP Bacterial Endotoxins Test is the official LAL test referenced in specific USP monographs (Bacterial Endotoxins Test, pp. 1696-1697. USP 23 NF 18. 1994. U.S. Pharmacopeial Convention, Inc., Rockville, MD) and has been applied to PM samples used in the RAIAP in vitro studies. The method is based on cleavage by endotoxin of pyrochrome into 4-nitroaninline, which absorbs at 540 $\mathrm{nm}$ and can be read in an enzyme-linked immunosorbent assay (ELISA) reader using microplates. It is more quantitative than the LAL test (http://www.acciusa.com/pdf/PyrochromeEnglish.pdf).

\section{Biological Effect Studies}

\section{In Vitro Inflammation Studies}

Primary rat alveolar macrophages and alveolar epithelium cells (Type 2, Crl/WKY rats, Harlan, UK) and a human alveolar epithelial cell line (A549, American Tissue Type Culture Collection, Rockville, MD) were used as in vitro model systems. Alveolar macrophages were collected by lung lavage; the Type-2 cells were isolated as previously described (Lag et al., 1996). Cells were cultured in a fetal bovine serum (FBS)-free medium from the start of particle exposure and the subsequent $6 \mathrm{~h}$; then FBS was added. After $20 \mathrm{~h}$ of exposure, the culture medium was collected. Analysis of the inflammatory cytokines was performed using ELISA according to the manufacturer's manual. Rat tumor necrosis-factor (TNF)-a and interleukin (IL)- 6 assays were from R\&D Systems Europe, Oxon, UK; the assays for human IL-8 and rat macrophage inflammatory protein (MIP)-2 were from Biosource International, Camarillo, CA.

\section{In Vivo Inflammation Studies}


Specific-pathogen-free inbred male BALB/c ByJ.ico mice (6-8 wk) were purchased from Charles River (L'Ardresle-Cedex, France), and male Wistar rats were obtained from the Nofer Institute of Occupational Medicine, Poland. Mice and rats were kept under standard conditions (up to 5 animals per cage, 12-h light-dark cycle, $22 \pm 28^{\circ} \mathrm{C}, 60 \pm 10 \%$ humidity), food pellets and tap water were available ad libitum. Before the experiment the animals were randomly divided into groups of eight animals each, and all animals were allowed to adapt to the housing conditions for at least $1 \mathrm{wk}$ before the experiments started. All experiments were performed according to international and institutional guidelines for animal care.

\section{Inflammation in Rats}

Rats were anesthetized using halothane $\sim 2.0 \% \mathrm{v} / \mathrm{v}$ and were instilled via a transoral tube. The rats were instilled with 1.0 and $2.5 \mathrm{mg}$ PM. Control rats received intratracheally saline (negative control) or 1.0 and $2.5 \mathrm{mg}$ of EHC-93 dust (reference sample; a gift of Dr. R. Vincent, Environmental and Occupational Toxicology Division, Environmental Health Directorate, Health Canada, Ottawa, Ontario, Canada). Twenty-four hours after instillation the rats were killed under ketamine/xylazine anesthesia. The right lung was lavaged in situ through the trachea twice with cold phosphate-buffered saline (2.5 ml per lavage). In BAL fluid the following measurements were performed: albumin, Clara cell protein, MIP-2, and TNF-a. Albumin was determined by latex immunoassay with antibodies from ICN Biomedicals (Costa Mesa, CA) with a standard based on pooled sera from normal rats. Clara cell protein (CC16) as a marker of bronchiolar epithelium damage was determined by latex immunoassay (Bernard et al., 2003; Halatek et al., 1998). Specific rabbit antibodies against CC16 and a standard based on the purified protein were obtained as described earlier (Bernard et al., 2003; Halatek et al., 1998).

\section{Local Popliteal Lymph Node Reactions}

The response to allergen and particles in BALB/c mice was measured as the popliteal lymph node response and allergen-specific IgE production in serum after subcutaneous injection into the footpad (Lovik et al., 1997; Ormstad et al., 1998). Mice were given the allergen ovalbumin ( $50 \mu \mathrm{g}$ per mouse) in the presence or absence of particles (100 and $200 \mu \mathrm{g}$ per mouse for measurements of the popliteal lymph node response and IgE antibody response, respectively). In the popliteal lymph node assay the effect of particles alone was examined as well. For measurements of the lymph node response mice were killed by cervical dislocation under $\mathrm{CO} 2$ anesthesia 6 days after immunization. Both popliteal lymph nodes were dissected out and kept on ice in HBSS before excess fat and connective tissue was removed and the lymph nodes weighed. Weight indices were calculated by dividing the value of the right (inoculated) lymph node with that of the left (noninoculated). For measurements of allergen-specific IgE antibodies, mice were given a second injection of ovalbumin 20 days after the first one, and 5 days later blood was drawn from the heart under $\mathrm{CO} 2$ anesthesia. Allergen-specific IgE antibodies in sera were determined by ELISA.

\section{Airway Sensitization in Mice}

The mice were randomly placed in groups $(n=8)$. For intranasal sensitization on days 0 and 14 , the mice were slightly anesthetized with halothane. At the moment of waking, $0.4 \mathrm{mg} / \mathrm{ml}$ ovalbumin (grade V, Sigma Chemical, St. Louis, MO) in a total of $50 \mu \mathrm{l}$ saline was administered into both nostrils. For the challenge, mice were again intransally exposed to ovalbumin at the same concentration on days 35,38 , and 41 . To study the effects of particles, the suspension of particles and ovalbumin were mixed to a final concentration of 0.4 $\mathrm{mg} / \mathrm{ml}$ ovalbumin and $3 \mathrm{mg} / \mathrm{ml}$ particles on day 0 and 14 . Animals were sacrificed on day 42, and IgE antibodies were determined according to the procedure described by (Steerenberg et al., 2003). For the histopathology of the lungs, 
lungs were fixed in $4 \%$ phosphate-buffered formaldehyde $(\mathrm{pH} 7.2)$ and embedded in paraplast. Five-micrometer sections were prepared and stained with hematoxylin and eosin (HE). The histopathological lesions were semiquantitatively and blindly scored for peribronchiolar infiltrate, perivascular infiltrate, hypertrophy of mucous cells, alveolitis, and eosinophils influx on a scale of absent (0), minimal (1), slight (2), moderate (3), marked (4), and strong (5). The incidence and the severity of the lesions were incorporated into this score.

\section{Statistical Analysis}

The biological effect parameters were log transformed after adding 0.5 to prevent difficulties with zero. To identify the correlation between the various biological effect markers, univariable Pearson correlation coefficients were calculated. Correlations above 0.4 and below -0.4 and depending on the $p$ values are regarded as biological relevant (Table 1 and Table 2 ). 
TABLE 1 Association between PM (coarse and fine) and key biological effect parameters in vivo and in vitro

Proinflammation in vitro

$\begin{array}{ccccccccccc}\text { Respiratory allergy } & \text { Systemic allergy } & \begin{array}{c}\text { Toxicity and proinflammation } \\ \text { in vivo }\end{array} & \begin{array}{c}\text { A549 } \\ \text { cells }\end{array} & \text { Rat macrophages } & \begin{array}{c}\text { Rat type } 2 \\ \text { cells }\end{array} \\ \text { IgE Pathology IgE } & \begin{array}{c}\text { Lymph node } \\ \text { wt. }\end{array} & \text { CC16 } & \text { Alb. } & \text { TNF-a } & \text { MIP2 } & \text { IL-8 } & \text { IL-6 } & \text { TNF-a IL-6 MIP-2 }\end{array}$

Effect

Parameter

IgE Pathology IgE

wt.

CC16

Alb. TNF-a MIP2

Note. Association between biological effect parameters in vivo and in vitro: coarse in terms of rounded off correlation coefficients. Respiratory allergy: ovalbumin after intranasal application. Systemic allergy: footpad sensitization by ovalbumin after intradermal injection. In vivo: toxicity study of particles $24 \mathrm{~h}$ after intratracheal instillation of PM. In vitro: Cytokine release from cell cultures after $20 \mathrm{~h}$ of exposure to PM (A549 cells: IL-8; rat lung macrophages: IL6; and TNF-a; rat Type 2 cells: IL-6 and MIP-2).

${ }^{a}$ Significant, $p<.05$.

Respiratory allergy

Systemic allergy

Toxicity and

proinflammation in vivo

\begin{tabular}{|c|c|c|c|c|}
\hline 1gE & & & & \\
\hline Pathology & $0.9^{a}$ & & & \\
\hline IgE & 0.0 & -0.0 & 1 & \\
\hline $\begin{array}{l}\text { Lymph-node } \\
\text { weight }\end{array}$ & 0.1 & 0.3 & 0.0 & 1 \\
\hline CC16 & 0.0 & 0.1 & -0.2 & 0.1 \\
\hline & Albumin & 0.1 & 0.2 & -0.0 \\
\hline TNF-a & 0.0 & 0.2 & 0.2 & 0.2 \\
\hline MIP-2 & 0.1 & 0.3 & 0.0 & 0.3 \\
\hline IL-8 & -0.0 & 0.1 & -0.0 & 0.1 \\
\hline IL-6 & -0.0 & 0.2 & -0.2 & 0.4 \\
\hline TNF-a & 0.2 & $0.5^{a}$ & 0.0 & $0.5^{a}$ \\
\hline IL-6 & -0.3 & -0.1 & -0.2 & 0.3 \\
\hline MIP-2 & -0.2 & 0.0 & $-0.4^{a}$ & 0.3 \\
\hline
\end{tabular}

$\begin{array}{ccc}1 & & \\ 0.2 & -0.0 & 1 \\ -0.2 & 0.5^{a} & 1 \\ 0.2 & 0.6^{a} & 0.8^{a} \\ 0.1 & 0.1 & -0.1 \\ 0.5^{a} & 0.3 & 0.2 \\ 0.4^{a} & 0.3 & 0.4 \\ 0.6^{a} & 0.2 & 0.1 \\ 0.5^{a} & 0.2 & 0.1\end{array}$




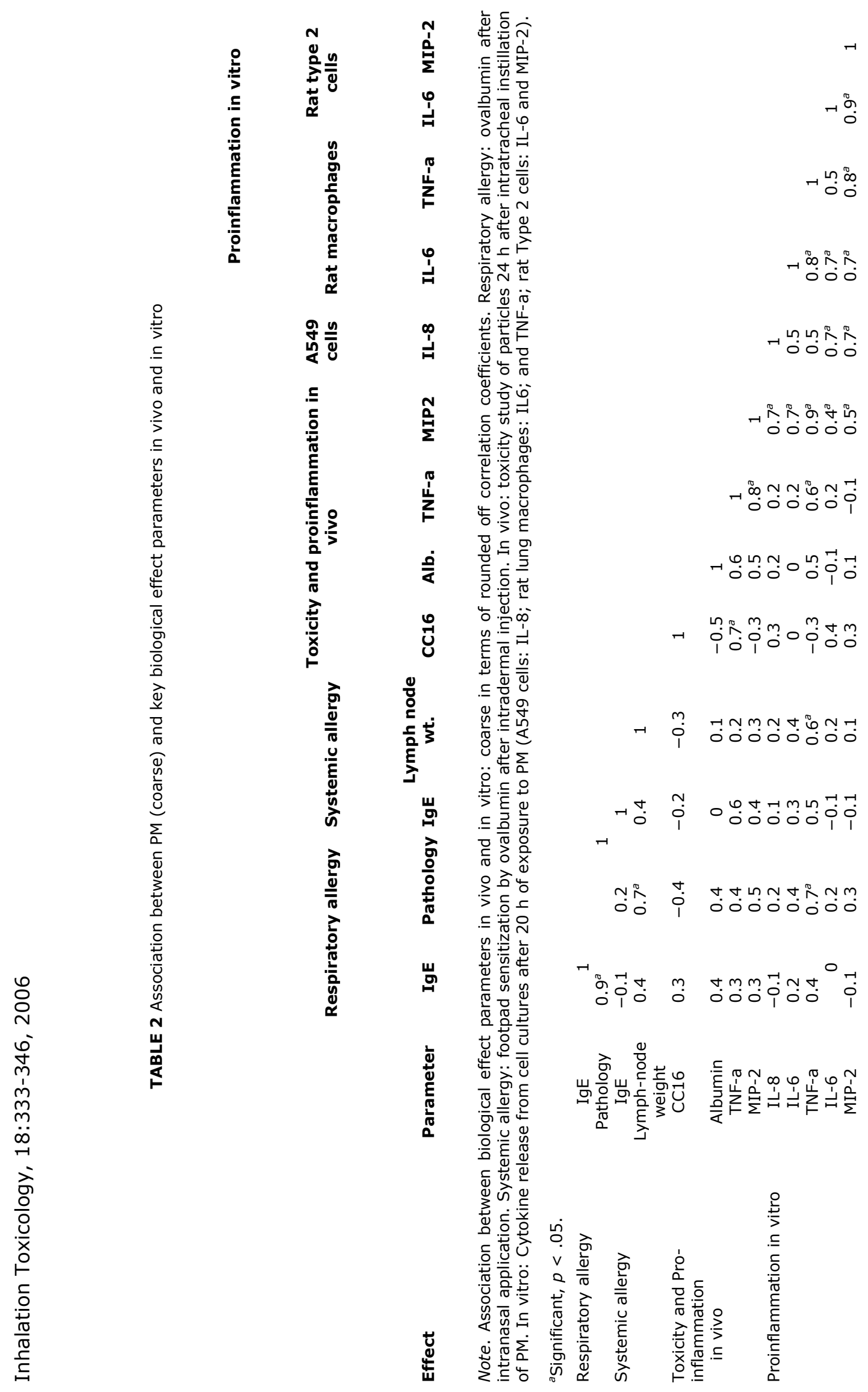


In a second step, univariable Pearson correlations between the chemical components and the thirteen selected biological effect parameters were calculated (Figure 1, Table 3 and Table 4) to express the magnitude of association between these parameters. Chemical components that resulted in a similar pattern of the biological effect parameters were clustered. Several cluster methods were assessed in which the number of clusters was determined by the distance coefficient and by visual inspection of the graph, representing the clustered data (as shown, for example, in Figure 1 ). Due to the relatively low number of samples $(n=26)$, no significant differences between the different clustering methods were found. The clusters presented in this article were selected by the complete linkage method with a fixed number of five clusters. In complete linkage, the distance between two clusters is the maximum distance between an observation in one cluster and an observation in the other cluster (Sorensen, 1948). For example, if component $A$ and $B$ both increase IgE, increase the TNF-a levels, and decrease the level of CC16 to the same magnitude, they were grouped to a specific cluster. Thus, each chemical component was assigned to a specific cluster as suggested by the data; cluster allocation was not defined a priori. This exercise resulted in five distinct clusters that were subsequently defined, based on their constituents present, to one or more contributing sources.

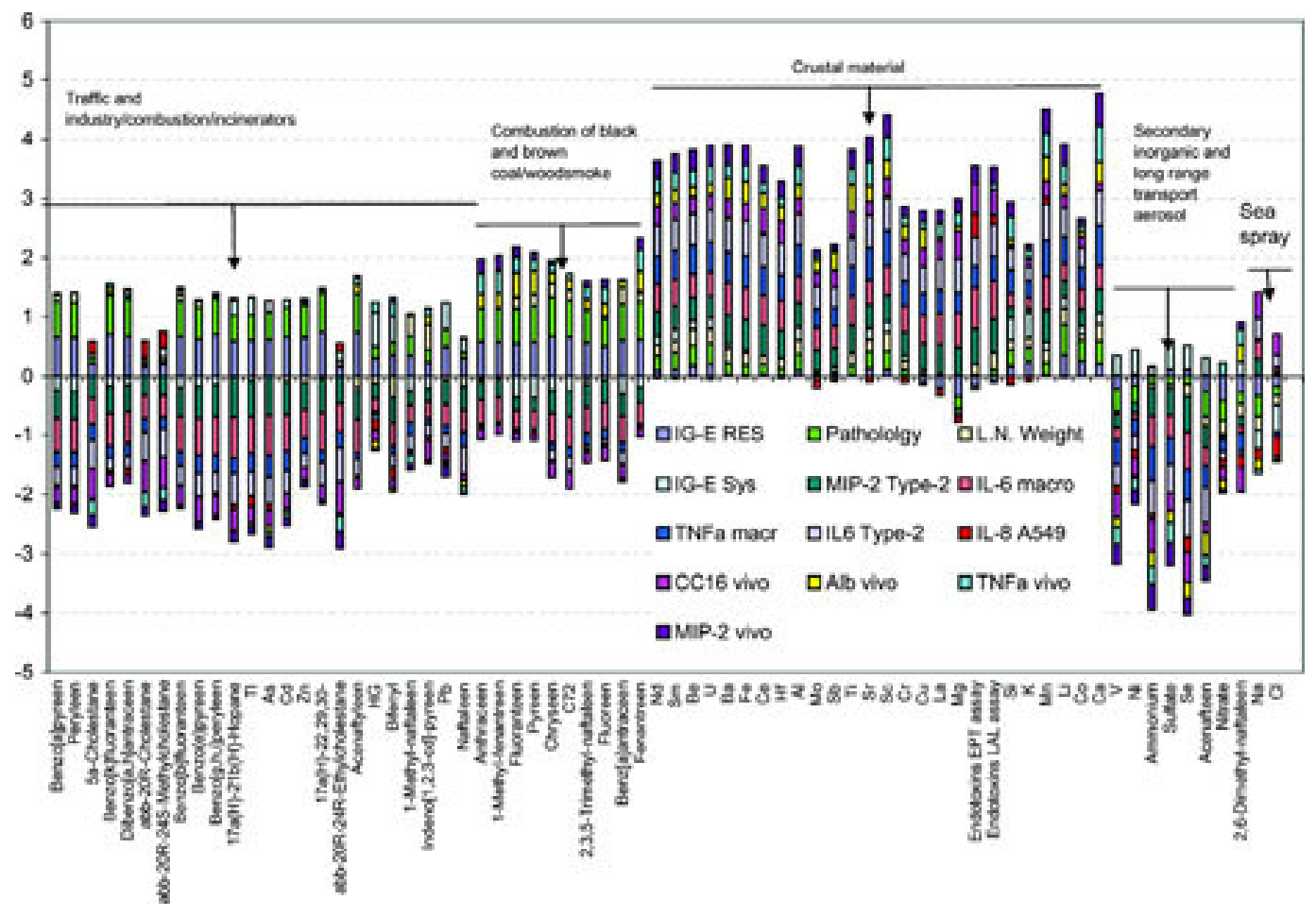

FIG. 1 All individual correlation coefficients between the health effect parameters and chemical components are represented. Different cluster patterns of the response parameters clearly emerge $(n=5)$. It was found that some health effect parameters were negatively associated with components of one source and positively associated with components of other source clusters. Full name of compound or element is listed in Table 3. 
TABLE 3 Cluster analysis of particle components and biological effects

Proinflammation in vitro

\section{Respiratory allergy Systemic allery}

Toxicity and proinflammation in vivo
A549,

cells Rat macrophages Rat type 2 cells

\section{Compound or element}

IgE Pathology IgE $\begin{gathered}\text { L-node } \\ \text { w. }\end{gathered}$

CC16 Alb. TNF a MIP2

IL-8

IL-6

TNFa

IL-6 MIP-2 Cluster

Note. Cluster 1: Traffic + industry/combustion/incinerators. Cluster 2: Combustion of brown and back coal and woodsmoke. Cluster 3: Crustal material. Cluster 4: Secondary inorganic aerosol and long-range transport aerosol. Cluster 5: sea spray.

Respiratory allergy: ovalbumin response after intranasal application. Systemic allergy response: sensitization to ovalbumin by intradermal injection in footpad. In vivo: short-term toxic effects of PM after intratracheal instillation. In vitro: cytokine release in supernatant of cell (lines) after exposure to PM (A549: IL-8; macrophage line: IL6, TNF-a, and IL-6; Type 2 cell: IL-6 and MIP-2).

\begin{tabular}{|c|c|c|c|c|c|c|c|c|c|c|}
\hline Benzo[a]pyrene & 0.66 & 0.60 & -0.25 & 0.12 & -0.27 & 0.04 & 0.00 & -0.10 & -0.05 & $\begin{array}{l}-0.57 \\
-0.56\end{array}$ \\
\hline Perylene & 0.65 & 0.59 & -0.26 & 0.16 & -0.26 & 0.01 & -0.03 & -0.13 & -0.04 & -0.56 \\
\hline 5a-Cholestane & 0.21 & 0.08 & 0.01 & 0.08 & -0.52 & -0.02 & -0.24 & -0.20 & 0.21 & -0.45 \\
\hline Benzo[k]fluoranthene & 0.70 & 0.66 & -0.18 & 0.04 & -0.20 & 0.08 & 0.07 & 0.00 & -0.05 & -0.55 \\
\hline Dibenzo[a,h]anthracene & 0.68 & 0.62 & -0.14 & -0.02 & -0.13 & 0.06 & 0.09 & 0.01 & -0.11 & -0.54 \\
\hline abb-20R-Cholestane & 0.16 & 0.04 & 0.04 & 0.06 & -0.52 & 0.00 & -0.25 & -0.16 & 0.29 & -0.39 \\
\hline abb-20R-24S-Methylcholestane & 0.19 & 0.04 & 0.15 & 0.08 & -0.52 & 0.01 & -0.22 & -0.17 & 0.28 & -0.36 \\
\hline Benzo[b]fluoranthene & 0.67 & 0.60 & -0.20 & 0.12 & -0.33 & 0.07 & 0.04 & -0.06 & -0.01 & -0.59 \\
\hline Benzo[e]pyrene & 0.62 & 0.53 & -0.19 & 0.11 & -0.40 & 0.03 & -0.01 & -0.12 & -0.02 & -0.63 \\
\hline Benzo[g,h,i]perylene & 0.70 & 0.61 & -0.15 & 0.01 & -0.31 & 0.05 & 0.04 & -0.07 & -0.07 & -0.64 \\
\hline $17 \mathrm{a}(H)-21 \mathrm{~b}(H)$-Hopane & 0.59 & 0.43 & 0.26 & -0.01 & -0.36 & 0.04 & -0.02 & -0.17 & -0.09 & -0.70 \\
\hline $\mathrm{TI}$ & 0.60 & 0.42 & 0.31 & -0.07 & -0.28 & -0.06 & 0.01 & -0.14 & -0.16 & -0.62 \\
\hline As & 0.61 & 0.47 & 0.19 & 0.01 & -0.26 & -0.11 & -0.07 & -0.19 & -0.11 & -0.67 \\
\hline $\mathrm{Cd}$ & 0.66 & 0.49 & 0.14 & -0.10 & -0.25 & -0.07 & -0.08 & -0.14 & -0.01 & -0.61 \\
\hline $\mathrm{Zn}$ & 0.65 & 0.54 & 0.05 & -0.11 & -0.20 & 0.01 & -0.04 & -0.08 & 0.05 & -0.49 \\
\hline $17 a(H)-22,29,30-$ Trisnorhopane & 0.75 & 0.65 & 0.05 & -0.05 & -0.27 & 0.02 & -0.01 & -0.04 & 0.01 & -0.64 \\
\hline
\end{tabular}

$\begin{array}{lll}-0.25 & -0.29 & -0.47 \\ -0.25 & -0.31 & -0.46 \\ -0.26 & -0.48 & -0.38 \\ -0.20 & -0.22 & -0.45 \\ -0.22 & -0.21 & -0.44 \\ -0.24 & -0.48 & -0.33 \\ -0.21 & -0.46 & -0.33 \\ -0.24 & -0.32 & -0.48 \\ -0.32 & -0.39 & -0.52 \\ -0.29 & -0.35 & -0.54 \\ -0.26 & -0.52 & -0.68 \\ -0.32 & -0.41 & -0.61 \\ -0.37 & -0.45 & -0.66 \\ -0.34 & -0.37 & -0.56 \\ -0.26 & -0.25 & -0.45 \\ -0.21 & -0.37 & -0.57\end{array}$




\begin{tabular}{|c|c|c|c|c|c|c|c|c|c|c|c|c|c|c|}
\hline abb-20R-24R-Ethylcholestane & 0.16 & -0.01 & 0.17 & 0.08 & -0.54 & -0.04 & -0.27 & -0.28 & 0.15 & -0.48 & -0.28 & -0.57 & -0.45 & \\
\hline Acenaphthylene & 0.74 & 0.65 & -0.07 & -0.19 & -0.18 & 0.14 & 0.11 & 0.06 & -0.04 & -0.57 & -0.11 & -0.28 & -0.47 & \\
\hline HG & 0.30 & 0.20 & 0.57 & -0.13 & -0.18 & -0.12 & 0.18 & -0.04 & -0.18 & -0.21 & -0.06 & -0.08 & -0.26 & \\
\hline Biphenyl & 0.34 & 0.23 & 0.43 & -0.37 & -0.14 & -0.07 & 0.25 & 0.08 & -0.21 & -0.39 & -0.14 & -0.22 & -0.43 & \\
\hline 1-Methyl-naphthylene & 0.33 & 0.34 & -0.25 & 0.34 & -0.06 & 0.06 & -0.17 & -0.10 & -0.02 & -0.29 & -0.21 & -0.24 & -0.25 & \\
\hline Indeno[ $[1,2,3-c d]$-pyrene & 0.22 & 0.23 & -0.23 & 0.42 & -0.33 & 0.15 & 0.13 & -0.05 & -0.07 & -0.28 & -0.09 & -0.23 & -0.21 & \\
\hline $\mathrm{Pb}$ & 0.49 & 0.30 & 0.46 & -0.07 & -0.12 & -0.05 & -0.04 & -0.18 & -0.11 & -0.36 & -0.13 & -0.23 & -0.41 & \\
\hline Nephthylene & 0.30 & 0.10 & 0.23 & -0.18 & -0.10 & -0.11 & -0.11 & -0.04 & 0.02 & -0.38 & -0.24 & -0.47 & -0.39 & \\
\hline Anthracene & 0.58 & 0.56 & -0.04 & -0.05 & -0.18 & 0.25 & 0.35 & 0.24 & -0.03 & -0.41 & -0.03 & -0.02 & -0.32 & \\
\hline 1-Methyl-fenanthrene & 0.58 & 0.57 & 0.00 & -0.05 & -0.18 & 0.25 & 0.38 & 0.26 & -0.04 & -0.41 & 0.00 & 0.00 & -0.32 & \\
\hline Fluoranthrene & 0.55 & 0.58 & -0.37 & 0.18 & -0.13 & 0.41 & 0.26 & 0.17 & -0.07 & -0.32 & -0.01 & 0.02 & -0.21 & \\
\hline Pyrene & 0.57 & 0.60 & -0.37 & 0.20 & -0.10 & 0.40 & 0.18 & 0.12 & -0.07 & -0.32 & -0.01 & -0.01 & -0.22 & \\
\hline Chrysene & 0.67 & 0.66 & -0.25 & 0.22 & -0.26 & 0.19 & 0.14 & 0.06 & -0.02 & -0.50 & -0.12 & -0.18 & -0.38 & \\
\hline $\mathrm{C} 72$ & 0.66 & 0.63 & -0.26 & 0.16 & -0.26 & 0.17 & 0.11 & 0.00 & -0.04 & -0.52 & -0.17 & -0.22 & -0.41 & \\
\hline 2,3,5-Trimethyl-naphthylene & 0.57 & 0.54 & -0.09 & -0.06 & -0.19 & 0.18 & 0.20 & 0.10 & -0.06 & -0.46 & -0.18 & -0.07 & -0.37 & \\
\hline Fluorene & 0.50 & 0.45 & 0.06 & -0.07 & -0.25 & 0.20 & 0.26 & 0.15 & -0.04 & -0.45 & -0.16 & -0.09 & -0.38 & \\
\hline Benz[a]anthracene & 0.61 & 0.59 & -0.32 & 0.28 & -0.22 & 0.12 & 0.02 & -0.05 & -0.03 & -0.45 & -0.15 & -0.21 & -0.35 & \\
\hline Fenanthrene & 0.61 & 0.64 & -0.19 & 0.14 & -0.15 & 0.35 & 0.35 & 0.22 & -0.06 & -0.37 & 0.01 & 0.02 & -0.27 & \\
\hline $\mathrm{Nd}$ & 0.09 & 0.24 & 0.16 & 0.19 & 0.33 & 0.20 & 0.26 & 0.31 & -0.04 & 0.45 & 0.48 & 0.52 & 0.42 & 3 \\
\hline Sm & 0.11 & 0.27 & 0.19 & 0.21 & 0.30 & 0.21 & 0.29 & 0.32 & -0.05 & 0.43 & 0.50 & 0.52 & 0.40 & 3 \\
\hline $\mathrm{Be}$ & 0.17 & 0.34 & 0.13 & 0.28 & 0.29 & 0.16 & 0.28 & 0.34 & -0.02 & 0.40 & 0.48 & 0.52 & 0.40 & 3 \\
\hline U & 0.19 & 0.36 & 0.17 & 0.25 & 0.27 & 0.17 & 0.31 & 0.34 & -0.06 & 0.40 & 0.51 & 0.54 & 0.38 & 3 \\
\hline $\mathrm{Ba}$ & 0.01 & 0.19 & 0.08 & 0.25 & 0.31 & 0.35 & 0.23 & 0.33 & 0.04 & 0.53 & 0.53 & 0.56 & 0.49 & 3 \\
\hline $\mathrm{Fe}$ & -0.01 & 0.18 & 0.06 & 0.20 & 0.31 & 0.36 & 0.28 & 0.33 & -0.01 & 0.54 & 0.56 & 0.58 & 0.50 & 3 \\
\hline $\mathrm{Ce}$ & 0.02 & 0.17 & 0.00 & 0.15 & 0.42 & 0.25 & 0.17 & 0.30 & 0.03 & 0.51 & 0.47 & 0.55 & 0.51 & 3 \\
\hline $\mathrm{Hf}$ & -0.02 & 0.13 & 0.00 & 0.16 & 0.38 & 0.25 & 0.15 & 0.26 & -0.01 & 0.50 & 0.44 & 0.52 & 0.49 & 3 \\
\hline Al & 0.09 & 0.27 & 0.21 & 0.25 & 0.28 & 0.21 & 0.32 & 0.34 & -0.01 & 0.45 & 0.52 & 0.53 & 0.41 & 3 \\
\hline Mo & -0.06 & 0.04 & 0.03 & 0.02 & 0.24 & 0.20 & 0.08 & 0.10 & -0.15 & 0.38 & 0.31 & 0.38 & 0.34 & 3 \\
\hline $\mathrm{Sb}$ & -0.05 & 0.03 & 0.09 & 0.04 & 0.30 & 0.31 & 0.05 & 0.08 & -0.03 & 0.38 & 0.31 & 0.33 & 0.31 & 3 \\
\hline $\mathrm{Ti}$ & 0.00 & 0.18 & 0.01 & 0.20 & 0.40 & 0.45 & 0.28 & 0.33 & 0.05 & 0.50 & 0.50 & 0.48 & 0.47 & 3 \\
\hline $\mathrm{Sr}$ & 0.13 & 0.28 & 0.19 & 0.21 & 0.24 & 0.25 & 0.42 & 0.41 & -0.10 & 0.41 & 0.55 & 0.55 & 0.39 & 3 \\
\hline Sc & 0.11 & 0.31 & 0.18 & 0.32 & 0.30 & 0.31 & 0.37 & 0.38 & 0.03 & 0.50 & 0.59 & 0.56 & 0.45 & 3 \\
\hline $\mathrm{Cr}$ & -0.02 & 0.11 & 0.10 & 0.13 & 0.26 & 0.21 & 0.16 & 0.18 & -0.09 & 0.44 & 0.41 & 0.47 & 0.40 & 3 \\
\hline $\mathrm{Cu}$ & -0.09 & 0.04 & -0.04 & 0.07 & 0.31 & 0.34 & 0.11 & 0.18 & -0.02 & 0.47 & 0.38 & 0.44 & 0.43 & 3 \\
\hline La & -0.20 & -0.02 & -0.01 & 0.04 & 0.31 & 0.06 & 0.23 & 0.22 & -0.11 & 0.52 & 0.39 & 0.53 & 0.49 & 3 \\
\hline $\mathrm{Mg}$ & -0.35 & -0.19 & -0.06 & -0.06 & 0.47 & 0.09 & 0.21 & 0.25 & -0.12 & 0.57 & 0.35 & 0.57 & 0.48 & 3 \\
\hline Endotoxins EPT assay & -0.15 & 0.01 & -0.07 & 0.18 & 0.51 & 0.00 & 0.00 & 0.30 & 0.37 & 0.68 & 0.37 & 0.50 & 0.61 & 3 \\
\hline Endotoxins LAL assay & -0.09 & 0.11 & 0.02 & 0.27 & 0.43 & -0.01 & 0.10 & 0.28 & 0.15 & 0.64 & 0.43 & 0.53 & 0.56 & 3 \\
\hline $\mathrm{Si}$ & 0.16 & 0.28 & 0.37 & 0.16 & 0.06 & 0.11 & 0.37 & 0.25 & -0.15 & 0.24 & 0.40 & 0.35 & 0.18 & 3 \\
\hline $\mathrm{K}$ & 0.23 & 0.25 & 0.42 & 0.16 & 0.12 & 0.04 & 0.12 & 0.09 & -0.08 & 0.17 & 0.28 & 0.25 & 0.08 & 3 \\
\hline $\mathrm{Mn}$ & 0.00 & 0.21 & 0.14 & 0.22 & 0.28 & 0.41 & 0.38 & 0.42 & 0.10 & 0.58 & 0.61 & 0.62 & 0.53 & 3 \\
\hline $\mathrm{Li}$ & 0.34 & 0.52 & 0.19 & 0.28 & 0.22 & 0.17 & 0.34 & 0.34 & -0.02 & 0.29 & 0.47 & 0.48 & 0.27 & 3 \\
\hline
\end{tabular}


Inhalation Toxicology, 18:333-346, 2006

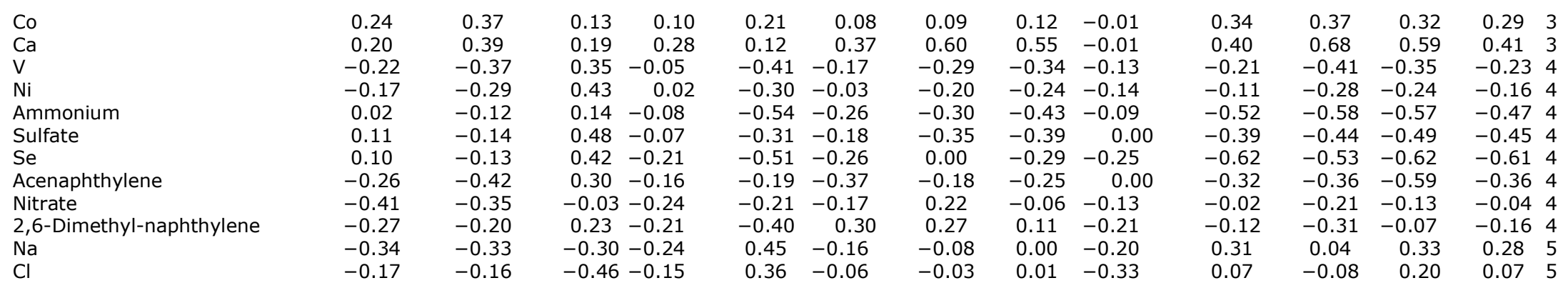


TABLE 4 Mean associations between effect parameters and constituents within the source clusters

Cluster

Increase correlation

\begin{tabular}{|c|c|c|c|c|c|}
\hline $\begin{array}{l}\text { Traffic and } \\
\text { industry/combustion/incinerators } \\
\text { (TICI) }\end{array}$ & $\begin{array}{l}\text { Resp. allergy } \\
\text { score } \\
\text { pathology } \\
0.4 \pm 0.2^{*}\end{array}$ & $\begin{array}{l}\text { Resp. allergy } \\
\text { IgE } 0.4 \pm 0.2\end{array}$ & & & \\
\hline $\begin{array}{l}\text { Combustion of black and brown } \\
\text { coal/wood smoke (BBCW) }\end{array}$ & $\begin{array}{l}\text { Short-term } \\
\text { tox. BAL } \\
\text { albumin } \\
0.3 \pm 0.2\end{array}$ & $\begin{array}{l}\text { Resp. allergy } \\
\text { score } \\
\text { pathology } \\
0.4 \pm 0.2\end{array}$ & $\begin{array}{l}\text { Resp. allergy } \\
\text { IgE } 0.5 \pm 0.2\end{array}$ & & \\
\hline Crustal material (CM) & $\begin{array}{l}\text { Short-term } \\
\text { tox. BAL CC16 } \\
0.3 \pm 0.1\end{array}$ & $\begin{array}{l}\text { In vitro } \\
\text { macrophage } \\
\text { IL-6 } 0.4 \pm 0.1\end{array}$ & $\begin{array}{c}\text { In vitro } \\
\text { macrophage } \\
\text { TNF-a } 0.5 \pm 0.1\end{array}$ & $\begin{array}{l}\text { In vitro } \\
\text { type } 2 \\
\text { MIP-2 } \\
0.5 \pm 0.1\end{array}$ & $\begin{array}{c}\text { In vitro } \\
\text { Rat type } 2 \\
\text { IL-6 } \\
0.5 \pm 0.1\end{array}$ \\
\hline $\begin{array}{l}\text { Secondary inorganic/long-range } \\
\text { aerosol (SIALT) }\end{array}$ & $\begin{array}{l}\text { Systemic } \\
\text { allergy IgE } \\
0.3 \pm 0.2\end{array}$ & & & & \\
\hline Sea spray (SS) & $\begin{array}{l}\text { In vitro } \\
\text { macrophage } \\
\text { IL-6 } 0.3 \pm 0.1\end{array}$ & $\begin{array}{l}\text { Short-term } \\
\text { tox. BAL CC16 } \\
0.5 \pm 0.1\end{array}$ & & & \\
\hline
\end{tabular}

\section{RESULTS}

\section{Chemical Characterization of the Particle Constituents}

\section{Elemental Composition}

In general, concentrations of metals were high in Rome with the exception of zinc. The location in Amsterdam is characterized by relatively high magnesium $(\mathrm{Mg})$ and vanadium $(\mathrm{V})$ levels in the coarse fraction during all three seasons. Lead $(\mathrm{Pb})$ and zinc $(\mathrm{Zn})$ where relatively high in the fine mode fraction in Lodz, with the highest levels in the winter. Iron ( $\mathrm{Fe})$, manganese $(\mathrm{Mn})$, aluminum ( $\mathrm{Al})$, chromium $(\mathrm{Cr})$, and copper $(\mathrm{Cu})$ were usually higher in the coarse fraction, whereas $\mathrm{Zn}, \mathrm{Pb}$, nickel $(\mathrm{Ni})$, and vanadium $(\mathrm{V})$ were higher in the fine fraction of PM. The former set of elements is typical for crustal material. The latter suite is often related to combustion sources such as traffic. There is no clear contrast in composition between the three seasons.

\section{Inorganic Constituents}

Nitrate, sulfate, ammonia, chloride, sodium, and potassium are the major constituents of the nonorganic part of the collected PM. The processing of the samples might cause losses of ammonium nitrate and as such the levels detected might be low estimates. Sea-spray aerosol, containing sodium chloride, was a substantial component of the samples collected at the sites in Amsterdam and De Zilk. Depending on the atmospheric aging of the particulate matter causing the depletion of chloride due to reaction with acids in the atmosphere, the ratio of sodium to chloride might shift to higher values than expected based on the composition of sea spray. Ammonia and sulfate were predominantly found in the fine fraction, irrespective of the sampling site or season. Nitrate was measured in both the fine and coarse fraction of PM, and the highest levels were observed for 
the Dutch locations. This observation complies with experiences in other studies. High levels of potassium were measured at the location in Rome.

\section{Organic Constituents}

The highest yields of PAHs were derived from the Lodz location, in particular during the winter season. The PAHs were found in both size fractions. The PAHs may reflect the type of fossil fuel used for heating in Lodz, namely, coal instead of natural gas or oil. A more diverse pattern was found for the traffic markers hopanes and steranes. Although generally higher amounts were found in the fine fraction, relatively high amounts of steranes were observed for both winter and summer samples of the location in Oslo, as well as the winter samples from Rome and the summer samples from Lodz. This pattern was not reflected in the hopane levels, which appeared to be more dominant in both the spring and winter samples from Lodz, Oslo, and Rome.

\section{Biological Effect Parameters}

The following parameters were obtained from in vitro and in vivo studies: for airway immunization, serum IgE response to ovalbumin and lung pathology; for subcutaneous immunization, lymph node weight and serum IgE response to ovalbumin; for short-term airway inflammation, constituents of BAL: CC16, albumin, TNF-a, and MIP-2; and for exposure of cells in vitro, PM-induced release of IL-8 (A549 cells), IL-6 (macrophage and Type-2 cells), MIP-2 (Type 2 cells), and TNF-a (macrophages). These biological effect parameters were selected on the basis of statistically significant associations with particles from Poland, Rome, Oslo, or Amsterdam (data not shown). In addition, all studies were based on particle mass concentrations and not on chemistry or surface area. In Table 1 it is shown that a number of biological endpoints are associated within cell lines, between cell lines, between cell lines and in vivo parameters, and between in vivo parameters, when coarse and fine particles were taken together. Correlations statistically significant $(p<.05)$ are regarded as relevant. Results from the in vitro experiments demonstrated a statistically significant association (correlation coefficient $0.3-0.8$ ) between particle-induced release of cytokines from the different types of lung cell cultures (A549, macrophage cell line Type 2 cell primary culture). Of the in vitro and in vivo biological effect parameters (shortterm respiratory inflammatory responses), MIP-2 was highly correlated with the in vitro inflammation parameters. No association was found between IgE evoked after intranasal instillation of ovalbumin and particles and IgE after subcutaneous injection of albumin and particles in the footpad. When the coarse fraction was analyzed separately (Table 2), a number of the statistical significantly associations disappeared (23 in Table 1 vs. 16 in Table 2). Regarding the fine fraction (table not shown), fewer statistically significantly correlations were found $(n=9)$.

\section{Clustering of Individual Components Based on Association}

A cluster analysis was performed in an attempt to simplify the large amount of data. The results of the cluster analysis are shown in Figure 1 and Table 3. The clusters are based on statistically similar correlation patterns between the different effect measures and the dust component concentrations. The bars in Figure 1 and the horizontal lines in Table 3 are similar. Based on the cluster analysis of the correlation between the components and biological effects, five clusters of components emerged. The emerging clusters were labeled on the basis of information from source apportionment studies. Importantly, the assignment of a component to one of the five clusters does not imply that this component is not present in any of the other clusters; however, it is less prominent. Endotoxins appear in two clusters (CM) and (SS) and illustrate the fact that the LAL assay and the pyrochrome test measure different types of endotoxins. 


\section{Association Between Source and Biological Effect Parameters}

In Figure 1 all individual correlation coefficients between the biological effect parameters and chemical components are represented. Five different cluster patterns of the response parameters clearly emerge $(n=5)$. It was found that some biological effect parameters were negatively associated with components of one source and positively associated with components of other source clusters. Correlation coefficients for most biological effect parameters with the concentrations of the chemical components labeled as cluster 1 (traffic and industry/combustion/incinerators, TICI) and cluster 4 (secondary inorganic and long-range transport aerosol, SIALT) were mostly negative (or inversely correlated), whereas for cluster 3 (crustal material, CM) most correlations were positive. Table 3 presents all individual correlation coefficients between the chemical constituent concentrations and the biological effect endpoints, and their clustering, In Table 4 the mean of the positive correlation coefficients of a cluster is presented, starting from 0.3. It is shown that within the cluster 1 (TICI) the pathological lesions and the increased concentrations of IgE after airway administration of allergen and particles showed rather strong correlation coefficients (0.4-0.5). Within cluster 2 (combustion of black and brown coal/wood smoke, BBCW), the albumin level and scores of lung pathology were correlated to the constituents and IgE (after airway administration) and with correlation coefficients $0.3,0.4$, and 0.5 , respectively. Within cluster $3(\mathrm{CM})$ the constituents and the five biological effect parameters were strongly associated (correlation coefficients 0.3-0.5), of which four were cytokines. In cluster 4 (SIALT), IgE level after subcutaneous injection showed a clear correlation (coefficient of 0.3 ) to the cluster constituents. Finally, the constituents in cluster 5 (sea spray, SS) and IL-6 from lung macrophages and CC16 from BAL showed clear correlations (coefficients of 0.3 and 0.5 , respectively).

\section{DISCUSSION}

It is hypothesized that inhaled PM will trigger a nonspecific response starting with irritation and short-term toxic effects. When PM is combined with allergen (ovalbumin), it can be speculated that allergens will be better processed due to nonspecific reactions induced by the irritating and short-term toxic effects properties of PM. In accordance with this hypothesis, the biological effect parameters in this study were selected to screen the collected particles on the basis of induction of nonspecific inflammation, toxicity, and adjuvant activity.

A strong correlation within the different in vitro models was demonstrated for the increased release of proinflammatory cytokines (TNF-a, IL-6, and MIP/IL-8), showing the importance of both alveolar macrophages and epithelial cells for particle-induced inflammatory responses (Table 1 ). In the in vivo inflammation model, a nonspecific inflammatory response was confirmed by a strong correlation between the inflammatory cytokines MIP-2 and TNF-a as well as with leakage of albumin in BAL. Furthermore, the particle-induced increase of MIP-2 in the in vitro and in vivo models was highly correlated (Table 1). Release of the chemokine MIP-2 (and the human analogue IL-8) plays an important role in the nonspecific inflammatory response by increasing the influx of neutrophils to the inflamed site (Driscoll et al., 1997). Effect on epithelial cells (Clara cells) in lung inflammation in vivo was also demonstrated by a marked reduction in CC16 in BAL after particle exposure. This result was also highly correlated with the cytokine release demonstrated in vitro. Thus, several inflammatory effect parameters in the in vitro and in vivo model correlated well, indicating that in vitro systems may be useful for predicting inflammatory responses in vivo. Moreover, the lower correlation between parameters might be due to the fact that markers were included only at one time point. 
The allergy screening tests in vivo using subcutaneous injection of allergen and particles into the footpad is partly a measure of irritation and short-term toxic effects and partly a measure of the specific immune response as far as the local lymph-node response is concerned. In contrast, specific IgE, IgG1, and IgG2a antibodies to ovalbumin in serum represent the specific immune response exclusively, with IgE being the hallmark of respiratory allergy. It is therefore not surprising that the lymph node weights are correlated with other measures of irritation such as TNF-a production in vitro (Table 1 ). The lack of correlation between the antibody responses after intranasal administration and subcutaneous injection into the footpad may be explained by anatomical factors. With subcutaneous injection, particles and allergen are presented directly to immune system cells, whereas after intranasal administration, the mucosal membrane must be passed. We hypothesize that with mucosal administration an inflammatory response is helpful and perhaps necessary for particles and allergen to cross the mucosal barrier to reach the draining lymph nodes and trigger an immune response, whereas after subcutaneous injection, the inflammatory response will not be necessary. Thus, the requirements for the induction of an immune response will be more complex after mucosal administration, with fewer samples meeting these requirements. This will lead to an apparently poor correlation between the adjuvant effect measured after mucosal and subcutaneous administration. This hypothesis is now being tested in ongoing studies. From Table 1 and Table 2 it can be seen that we have the best correlation between the different biological effect parameters for the coarse fractions. This is in line with the hypothesis that inflammation is necessary for the induction of an immune response and IgE production after intranasal administration, as far as inflammation then would be a shared component for most of the biological parameters.

The decreasing number of associations in the separately analyzed subgroups (coarse and fine) might be due to the lack of statistical power, because of the decreased number of samples, but may also be taken as an indication that coarse and fine fractions have in part different biological effects. So far, these results have to be interpreted with caution. In general, we conclude that for most of the biological effect parameters (irritation, toxicity, and adjuvant activity) a strong intracorrelation within the class of parameters is present. Further, between the irritation (cytokines) and toxicity measures a strong intercorrelation was found. This is in some contrast to the relation between irritation and toxicity measures and measures for adjuvant activity of immune responses to allergens, in particular if the subcutaneous route of immunization is taken into consideration. This points to a conclusion that more than one biological effect parameter has to be used to survey the potential toxicity of particles.

The influence of one single constituent in a mixture, such as PM (which itself is a complex mixture), is difficult to determine since it is likely that more than one component will play a role in the induction of the biological responses. For policy reasons it would be useful to identify the contributing source to the observed adverse health effects, rather than using single components. Although the RAIAP project did not aim to perform source apportionment on the collected PM samples, a substantial database on chemical characteristics of the PM samples was established. It was assumed that each of the major sources has a fixed (or nearly constant) emission profile. Rather than using the standard techniques to identify source contribution, the present study used the biological effects as the basis for grouping PM components into five clusters. Chemical constituents were grouped when they resulted in a similar response pattern in all 13 different bioassays. Although other statistical approaches were considered, the number of 26 PM samples in total limited the use of more sophisticated regression models. After mapping the association between biological effect parameters and individual 
components, cluster analysis was used to group individual components (Figure 1 and Table 3). Chances are that two components that appear to have similar effects may act by similar mechanisms (although not necessarily so), or perhaps more likely, one component may be the true effector component and the others merely appear to be active because they are associated with the first one, or alternatively all measured components may just be markers of a nonmeasured chemical component or other nonchemical particle property such as particle size and/or surface morphology.

Due to the limited number of samples the first cluster is a collection of different combustion profiles emitted by traffic, industry, and incinerators (Figure 1 and Table 3). Traffic is characterized by the elements $\mathrm{Zn}, \mathrm{Pb}, \mathrm{Hg}$, and a large number of organics such as hopanes and steranes (Cyrys et al., 2003; Schauer et al., 2002). This cluster (1) was identified based on the same response pattern of the markers (IgE and increased lung pathology) for respiratory adjuvant activity, suggesting that PM originating from traffic, industry combustion, and/or incinerators may play a role in allergy (Table 4). There is a body of evidence in the literature that indeed traffic emissions are associated with respiratory allergy (Fujimaki et al., 2001; Kramer et al., 2000; Nel et al., 1998; Steerenberg et al., 2003; Wjst et al., 1993).

The second cluster is marked by PAHs (Schauer et al., 2001). It has been shown that combustion of black and brown coal/wood smoke is characterized by high concentrations of these substances (Table 3). The wood smoke consists of fine carbonaceous particles $(<1 \mu \mathrm{m})$ that form large chains and aggregates having a size distribution of $63-74 \%$ in the $<1 \mu \mathrm{m}$ fraction and $26-37 \%$ in the $>1 \mu \mathrm{m}$ fraction. Wood smoke is known to be a risk factor for environmentally induced asthma (Boman et al., 2003; Glovsky et al., 1997; Schei et al., 2004; Utell \& Looney, 1995). In our study it was found that only the respiratory allergy model is associated with components of wood smoke (Table 4). A third cluster is dominated by a large number of elements ( $\mathrm{Al}, \mathrm{Si}, \mathrm{K}, \mathrm{Ca}, \mathrm{Fe})$. In general, these elements are also associated within the coarse fraction of PM (Watson \& Chow, 2001), although $\mathrm{K}$ is also a typical marker for wood smoke. This cluster was brought about by the health effect markers for pulmonary irritation and acute toxicity, for example, CC16, TNF-a, MIP-2, IL-6, and to a lesser extent albumin. This is in line with studies of Claiborn et al. (2002) and Pope et al. (1999) that indicated that stagnant air pollution episodes with primary and secondary combustion-source particles were more associated with asthma complaints than windblown dust episodes of coarse crustal particles.

The fourth cluster is characterized by the ions $\mathrm{SO} 42+, \mathrm{NH} 4+$, and $\mathrm{NO} 3-$ and the elements $\mathrm{V}, \mathrm{Ni}$, and Se (Table 3 ). These ions are very typical for secondary inorganic aerosol, whereas $\mathrm{V}$ and $\mathrm{Ni}$ are associated with long-range transport of particulate matter in source apportionment studies (Gaffney \& Marley, 2003; Lazaridis et al., 2002; Schauer et al., 2002). Long-range transport of particulate matter contributes significantly to the background particle mass and number size distribution and may be part of the association with a wide range of adverse health effects (Lazaridis et al., 2002). In our study only the IgE response induces effects after intracutaneous administration of ovalbumin and particulate matter was associated with this cluster (Table 3 and Table 4). However, looking at individual components, the IgE response after subcutaneous immunisation tended to be associated also with a number of markers of combustion sources.

The fifth cluster, sea salt spray, is characterized by $\mathrm{Na}$ and $\mathrm{Cl}$ and is statistically strongly correlated to CC16, which is a product from the Clara cell (Table 3 and Table 4). Although saline at physiological levels is innocuous, high concentrations of $\mathrm{Cl}$ may influence the production of Clara-cell protein (Table 4). In our studies 
endotoxin measured with a new method was also associated (correlation coefficient 0.5 ) with $\mathrm{CC} 16$ release. The reduction in CC16 could be explained by leakage of the protein into the blood or by this protein being used up in its antiinflammatory and antioxidant function (Johnston et al., 1999).

In conclusion, the present exploratory study shows that PM can induce a wide range of biological responses that are often not very well correlated. This clearly suggests that various mechanisms can play a role in the PM-associated health effects. Second, by using the biological endpoint from experimental studies in combination with chemical characteristics of PM, the impact of various sources can be assessed on a qualitative, but not quantitative, basis. The IgE response and increased lung pathology after airway immunization seem more associated with combustion sources, whereas inflammation and toxicity are more associated with crustal material.

\section{ACKNOWLEDGEMENT}

This investigation took place within the EU study entitled "Respiratory Allergy and Inflammation Due to Ambient Particles-A European-wide Study" (RAIAP, CLRT2000-00792). 


\section{REFERENCES}

Bernard, A., Carbonnelle, S., Michel, O., Higuet, S., De Burbure, C., Buchet, J. P., Hermans, C., Dumont, X., and Doyle, I. Lung hyperpermeability and asthma prevalence in schoolchildren: Unexpected associations with the attendance at indoor chlorinated swimming pools. Occup. Environ. Med. (2003), 60: 385-394.

Boman, B. C., Forsberg, A. B., and Jarvholm, B. G. Adverse health effects from ambient air pollution in relation to residential wood combustion in modern society. Scand. J. Work Environ. Health (2003), 29: $251-260$.

Cassee, F. R., and Boere, A. J. Respiratory allergy and inflammation due to ambient particles (RAIAP). A European-wide assessment. In Description of sampling framework and the precise locations in 4 cities and a seaside site, (2001) www.raiap.org.

Claiborn, C. S., Larson, T., and Sheppard, L. Testing the metals hypothesis in Spokane, Washington. Environ. Health Perspect. (2002), 110(suppl. 4): 547-552.

Cyrys, J., Stolzel, M., Heinrich, J., Kreyling, W. G., Menzel, N., Wittmaack, K., Tuch, T., and Wichmann, H. E. Elemental composition and sources of fine and ultrafine ambient particles in Erfurt, Germany. Sci. Total Environ. (2003), 305: 143-156.

Demokritou, P., Kavouras, I. G., Harrison, D., and Koutrakis, P. Development and evaluation of an impactor for a PM2.5 speciation sampler. J. Air Waste Manage. Assoc. (2001), 51: 514-523.

Demokritou, P., Gupta, T., Ferguson, S., and Koutrakis, P. Development and laboratory performance evaluation of a personal cascade impactor. J. Air Waste Manage. Assoc. (2002), 52: 1230-1237.

Dick, C. A., Singh, P., Daniels, M., Evansky, P., Becker, S., and Gilmour, M. I. Murine pulmonary inflammatory responses following instillation of size-fractionated ambient particulate matter. J. Toxicol. Environ. Health A (2003), 66: 2193-2207.

Donaldson, K., and Stone, V. Current hypotheses on the mechanisms of toxicity of ultrafine particles. Ann. Ist. Super. Sanita (2003), 39: 405-410.

Driscoll, K. E., Carter, J. M., Hassenbein, D. G., and Howard, B. Cytokines and particle-induced inflammatory cell recruitment. Environ. Health Perspect. (1997), 105(suppl. 5): 1159-1164.

Dybing, E., Lovdal, T., Hetland, R. B., Lovik, M., and Schwarze, P. E. Respiratory allergy adjuvant and inflammatory effects of urban ambient particles. Toxicology (2004), 198: 307-314.

Dye, J. A., Lehmann, J. R., McGee, J. K., Winsett, D. W., Ledbetter, A. D., Everitt, J. I., Ghio, A. J., and Costa, D. L. Acute pulmonary toxicity of particulate matter filter extracts in rats: coherence with epidemiologic studies in Utah Valley residents. Environ. Health Perspect. (2001), 109(suppl 3): 395403.

Feron, V. J., Groten, J. P., van Zorge, J. A., Cassee, F. R., Jonker, D., and van Bladeren, P. J. Toxicity studies in rats of simple mixtures of chemicals with the same or different target organs. Toxicol. Lett. (1995), 82-83: 505-512.

Fujimaki, H., Ushio, H., Nohara, K., and Ui, N. Induction of the imbalance of helper T-cell functions in mice exposed to diesel exhaust. Sci. Total Environ. (2001), 270: 113-121.

Gaffney, J. S., and Marley, N. A. Atmospheric chemistry and air pollution. Sci. World J. (2003), 3: 199-234.

Gavett, S. H., Haykal-Coates, N., Copeland, L. B., Heinrich, J., and Gilmour, M. I. Metal composition of ambient PM2.5 influences severity of allergic airways disease in mice. Environ. Health Perspect. (2003), 111: 1471-1477.

Ghio, A. J., Hall, A., Bassett, M. A., Cascio, W. E., and Devlin, R. B. Exposure to concentrated ambient air particles alters hematologic indices in humans. Inhal. Toxicol. (2003), 15: 1465-1478.

Glovsky, M. M., Miguel, A. G., and Cass, G. R. Particulate air pollution: Possible relevance in asthma. Allergy Asthma Proc. (1997), 18: 163-166.

Halatek, T., Hermans, C., Broeckaert, F., Wattiez, R., Wiedig, M., Toubeau, G., Falmagne, P., and Bernard, A. Quantification of Clara cell protein in rat and mouse biological fluids using a sensitive immunoassay. Eur. Respir. J. (1998), 11: 726-733. 
Hetland, R. B., Cassee, F. R., Refsnes, M., Schwarze, P. E., Lag, M., Boere, A. J., and Dybing, E. Release of inflammatory cytokines, cell toxicity and apoptosis in epithelial lung cells after exposure to ambient air particles of different size fractions. Toxicol. In Vitro (2004), 18: 203-212.

Johnston, C. J., Finkelstein, J. N., Oberdorster, G., Reynolds, S. D., and Stripp, B. R. Clara cell secretory protein-deficient mice differ from wild-type mice in inflammatory chemokine expression to oxygen and ozone, but not to endotoxin. Exp. Lung Res. (1999), 25: 7-21.

Kramer, U., Koch, T., Ranft, U., Ring, J., and Behrendt, H. Traffic-related air pollution is associated with atopy in children living in urban areas. Epidemiology (2000), 11: 64-70.

Lag, M., Becher, R., Samuelsen, J. T., Wiger, R., Refsnes, M., Huitfeldt, H. S., and Schwarze, P. E. Expression of CYP2B1 in freshly isolated and proliferating cultures of epithelial rat lung cells. Exp. Lung Res. (1996), 22: 627-649.

Lambert, A. L., Dong, W., Winsett, D. W., Selgrade, M. K., and Gilmour, M. I. Residual oil fly ash exposure enhances allergic sensitization to house dust mite. Toxicol. Appl. Pharmacol. (1999), 158: 269-277.

Lambert, A. L., Dong, W., Selgrade, M. K., and Gilmour, M. I. Enhanced allergic sensitization by residual oil fly ash particles is mediated by soluble metal constituents. Toxicol. Appl. Pharmacol. (2000), 165: 84-93.

Lazaridis, M., Semb, A., Larssen, S., Hjellbrekke, A. G., Hov, O., Hanssen, J. E., Schaug, J., and Torseth, K. Measurements of particulate matter within the framework of the European Monitoring and Evaluation Programme (EMEP) I. First results. Sci. Total Environ. (2002), 285: 209-235.

Lee, S. W. Source profiles of particulate matter emissions from a pilot-scale boiler burning North American coal blends. J. Air Waste Manage. Assoc. (2001), 51: 1568-1578.

Long, C. M., Suh, H. H., Kobzik, L., Catalano, P. J., Ning, Y. Y., and Koutrakis, P. A pilot investigation of the relative toxicity of indoor and outdoor fine particles: In vitro effects of endotoxin and other particulate properties. Environ. Health Perspect. (2001), 109: 1019-1026.

Lovik, M., Hogseth, A. K., Gaarder, P. I., Hagemann, R., and Eide, I. Diesel exhaust particles and carbon black have adjuvant activity on the local lymph node response and systemic IgE production to ovalbumin. Toxicology (1997), 121: 165-178.

Marcazzan, G. M., Ceriani, M., Valli, G., and Vecchi, R. Source apportionment of PM10 and PM2.5 in Milan (Italy) using receptor modelling. Sci. Total Environ. (2003a), 317: 137-147.

Marcazzan, G. M., Ceriani, M., Valli, G., and Vecchi, R. Source apportionment of PM10 and PM2.5 in Milan (Italy) using receptor modelling. Sci. Total Environ. (2003b), 317: 137-147.

Motallebi, N., Taylor, C.-A. J., Turkiewicz, K., and Croes, B. E. Particulate matter in California: Part 1Intercomparison of several PM2.5, PM10-2.5, and PM10 monitoring networks. J. Air Waste Manage. Assoc. (2003), 53: 1509-1516.

Nel, A. E., Diaz-Sanchez, D., Ng, D., Hiura, T., and Saxon, A. Enhancement of allergic inflammation by the interaction between diesel exhaust particles and the immune system. J. Allergy Clin. Immunol. (1998), 102: 539-554.

Nygaard, U. C., Samuelsen, M., Aase, A., and Lovik, M. The capacity of particles to increase allergic sensitization is predicted by particle number and surface area, not by particle mass. Toxicol. Sci. (2004), 82: 515-524.

Ormstad, H., Gaarder, P. I., Johansen, B. V., and Lovik, M. Airborne house dust elicits a local lymph node reaction and has an adjuvant effect on specific IgE production in the mouse. Toxicology (1998), 129: $227-236$.

Pope, C. A., Hill, R. W., and Villegas, G. M. Particulate air pollution and daily mortality on Utah's Wasatch Front. Environ. Health Perspect. (1999), 107: 567-573.

Quant, C., Fischer, P., Buringh, E., Ameling, C., Houthuijs, D., and Cassee, F. Application of principal component analysis to time series of daily air pollution and mortality, (2003) RIVM rapport 650010035 http://www.rivm.nl/bibliotheek/rapporten/650010035.pdf.

Salonen, R. O., Halinen, A. I., Pennanen, A. S., Hirvonen, M. R., Sillanpaa, M., Hillamo, R., Shi, T., Borm, P., Sandell, E., Koskentalo, T., and Aarnio, P. Chemical and in vitro toxicologic characterization of wintertime and springtime urban-air particles with an aerodynamic diameter below 10 microm in Helsinki. Scand J Work Environ Health (2004), 30(suppl. 2): 80-90. 
Salonen, R. O., Pennanen, A. S., Halinen, A. I, Hirvonen, M. R., Sillanpaa, M., Hillamo, R., Karlsson, V., Koskentalo, T., Aarnio, P., Ferguson, S., and Koutrakis, P. A chemical and toxicological comparison of urban air PM10 collected during winter and spring in Finland. Inhalation. Toxicol. (2000), 12(suppl. 103):.

Schauer, J. J., Kleeman, M. J., Cass, G. R., and Simoneit, B. R. Measurement of emissions from air pollution sources. 3. C1-C29 organic compounds from fireplace combustion of wood. Environ. Sci. Technol. (2001), 35: 1716-1728.

Schauer, J. J., Kleeman, M. J., Cass, G. R., and Simoneit, B. R. Measurement of emissions from air pollution sources. 5. C1-C32 organic compounds from gasoline-powered motor vehicles. Environ. Sci. Technol. (2002), 36: 1169-1180.

Schei, M. A., Hessen, J. O., Smith, K. R., Bruce, N., McCracken, J., and Lopez, V. Childhood asthma and indoor woodsmoke from cooking in Guatemala. J. Expos. Anal. Environ. Epidemiol. (2004), 14(suppl. 1): S110-S117.

Sorensen, T. A method of establishing groups of equal amplitude in plant sociology based on similarity of species content and its application to analyses of the vegetation on Danish commons. Biol. Skrifter (1948), 5: 1-34.

Steerenberg, P. A., Withagen, C. E., Dormans, J. A., van Dalen, W. J., van Loveren, H., and Casee, F. R. Adjuvant activity of various diesel exhaust and ambient particles in two allergic models. J. Toxicol. Environ. Health A (2003), 66: 1421-1439.

Steerenberg, P. A., Withagen, C. E., van Dalen, W. J., Dormans, J. A., Cassee, F. R., Heisterkamp, S. $\mathrm{H}$., and van Loveren, $\mathrm{H}$. Adjuvant activity of ambient particulate matter of different sites, sizes, and seasons in a respiratory allergy mouse model. Toxicol. Appl. Pharmacol. (2004a), 200: 186-200.

Steerenberg, P. A., Withagen, C. E., van Dalen, W. J., Dormans, J. A., and van Loveren, H. Adjuvant activity of ambient particulate matter in macrophage activity-suppressed, $\mathrm{N}$-acetylcysteine-treated, iNOS- and IL-4-deficient mice. Inhal. Toxicol. (2004b), 16: 835-843.

Steerenberg, P. A., Withagen, C. E., van Dalen, W. J., Dormans, J. A., Heisterkamp, S. H., van Loveren, H., and Cassee, F. R. Dose dependency of adjuvant activity of particulate matter from five European sites in three seasons in an ovalbumin-mouse model. (2005), 17: 133-145.

Utell, M. J., and Looney, R. J. Environmentally induced asthma. Toxicol. Lett. (1995), 82-83: 47-53.

Voelkel, K., Krug, H. F., and Diabate, S. Formation of reactive oxygen species in rat epithelial cells upon stimulation with fly ash. J. Biosci. (2003), 28: 51-55.

Watson, J. G., and Chow, J. C. Source characterization of major emission sources in the Imperial and Mexicali Valleys along the US/Mexico border. Sci. Total Environ. (2001), 276: 33-47.

Wjst, M., Reitmeir, P., Dold, S., Wulff, A., Nicolai, T., Loeffelholz-Colberg, E. F., and von Mutius, E. Road traffic and adverse effects on respiratory health in children. Br. Med. J. (1993), 307: 596-600.

Zhu, Y. J., Olson, N., and Beebe, T.-P. J. Surface chemical characterization of 2.5-micron particulates (PM2.5) from air pollution in Salt Lake City using TOF-SIMS, XPS, and FTIR. Environ. Sci. Technol. (2001), 35: 3113-3121. 